\title{
The Thymic Repertoire of Neuroendocrine-Related Self Antigens: Biological Role in T-Cell Selection and Pharmacological Implications
}

\author{
Vincent Geenen Ouafae Kecha Fabienne Brilot Chantal Charlet-Renard \\ Henri Martens \\ Institute of Pathology CHU-B23, Laboratory of Radioimmunology and Neuroendocrine-Immunology, \\ University of Liège, Belgium
}

\section{Key Words}

Thymus · Neuropeptides $\cdot$ Self tolerance $\cdot$ Autoimmunity

\begin{abstract}
Thymic epithelium, including nurse cells (TEC/TNC), as well as other thymic stromal cells (macrophages and dentritic cells), express a repertoire of polypeptide belonging to various neuroendocrine protein families (such as the neurophypophysial, tachykinin, neurotensin and insulin families). A hierarchy of dominance exists in the organization of the thymic repertoire of neuroendocrine precursors. Oxytocin (OT) is more expressed in the TEC/ TNC than vasopressin (VP); insulin-like growth factor 2 (IGF-2) thymic expression predominates over IGF-1, and much more over (pro)insulin. Thus, OT was proposed to be the self antigen of the neurohypophysial family, and IGF-2 the self antigen precursor of the insulin family. The dual role of the thymus in T-cell life and death is recapitulated at the level of the thymic neuroendocrine protein repertoire. Indeed, thymic polypeptides behave as accessory signals involved in T-cell development and positive selection according to the cryptocrine model of signaling. Moreover, thymic neuroendocrine polypeptides are the source of self antigens presented by thymic MHC
\end{abstract} molecules to developing pre-T cells. This presentation

\begin{tabular}{ll}
\hline KARGER & ( 1999 S. Karger AG, Basel \\
Fax +4161306 12 34 & Ac1-7401/99/0062-0115\$17.50/0 \\
$\begin{array}{l}\text { E-Mail karger@karger.ch } \\
\text { www.karger.com }\end{array}$ & Accessible online at: \\
http://BioMedNet.com/karger
\end{tabular}

might induce the negative selection of $T$ cells bearing a randomly rearranged antigen receptor (TCR) oriented against neuroendocrine families. Using an animal model of autoimmune type 1 diabetes (BB rat), we have shown a defect in intrathymic expression of the self antigen of the insulin family (IGF-2) and in IGF-2-mediated T-cell education to recognize and tolerate the insulin family. Altogether these studies have enlighted the crucial role played by the thymus in the induction of the central self tolerance of neuroendocrine families. The tolerogenic properties of thymic self peptides could be used in a novel type of vaccination for the prevention of autoimmune diseases.

\section{Introduction}

For a long time the thymus was considered to be an intrinsic component of the endocrine system though the endocrine model of cell-to-cell signalling had not been fully validated for this organ. With the discovery of its primary role in T-lymphopoiesis [1], the endocrine role of the thymus progressively vanished. In the past 15 years, the question of a neuroendocrine component in thymic physiology was reinvestigated. From a number of studies,

\footnotetext{
Vincent Geenen, MD, PhD

Institute of Pathology CHU-B23

University of Liège-Sart Tilman

B-4000 Liège 1-Sart Tilman (Belgium)

Tel. +32 436625 50, Fax +32436629 77, E-Mail vgeenen@ulg.ac.be
} 
it now appears that the thymus represents a crucial site for a cross-talk between the neuroendocrine and immune systems, in particular during fetal development. Thymic epithelial and stromal cells express a repertoire of neuroendocrine-related genes/protein precursors. It was shown that thymic polypeptides may serve as signals interacting with their cognate neuroendocrine receptors on developing pre-T lymphocytes. This cryptocrine form of cell-tocell signaling could play a role in T-cell development and maturation. On the other side, there is ample evidence that thymic neuroendocrine-related polypeptides also behave as a source of self antigens which are presented to pre-T cells and are thought to induce the negative selection of $\mathrm{T}$ cells bearing a randomly rearranged antigen receptor (TCR) oriented against endogenous neuroendocrine families (self-reactive $\mathrm{T}$ cells). The objective of this review is to expose most of the scientific arguments which support the important role of the thymus in the education of $\mathrm{T}$ lymphocytes to recognize and tolerate neuroendocrine functions.

\section{The Establishment of Immunological Self Tolerance}

The process of self tolerance induction involves a multilayered organization in which various tolerizing mechanisms are interconnected in series, from the early steps in immune cell ontogeny to an advanced stage in life [2]. With regard to the T-lymphocyte system, the primary tolerizing steps occur within the thymus, the primary lymphoid organ responsible for T-cell differentiation. To complete their differentiative program, immature $\mathrm{T}$ cells receive a series of signals from the thymic cellular microenvironment. Such activatory signals may be emitted by thymic stromal cells (like hormones or cytokines) or may result from direct interactions between cell adhesion molecules expressed on pre-T cells (thymocytes) and thymic stromal cells [3, 4]. Along their differentiation, immature $\mathrm{T}$ cells randomly rearranged the genes coding for the segments of their TCR. A lot of these random TCR combinations are oriented against self antigens which are expressed in the thymic microenvironment, then presented by proteins encoded in the major histocompatibility complex (MHC). The interaction of self-reactive T-cell clones with their cognate self antigens is thought to lead to their negative selection either by programmed cell death (apoptosis), or by their developmental arrest. This process of thymic clonal deletion was demonstrated with the use of MMTV (mouse mammary tumor virus)-encoded su- perantigens [5], and with transgenic mice expressing a TCR specific for the male antigen H-Y [6]. Since the thymus does not express all the components of the self structure, this organ does not delete all potential autoreactive $T$ cells. Consequently, the existence of other tolerizing mechanisms (such as T-cell anergy) at the periphery was postulated, and they were effectively shown to intervene in the process of immunological self tolerance. Nevertheless, thymic clonal deletion of self-reactive T cells is by far the most important mechanism involved in self education of the immune system [7].

\section{Thymic T-Cell Life and Death}

Self peptides are not only involved in the induction of central T-cell self tolerance but they also intervene in the process of $\mathrm{T}$-cell maturation or positive selection [8]. Thus, the thymus is the site for an important paradox of contemporary cell biology: How can $\mathrm{T}$ lymphocytes be both positively and negatively selected in the thymic microenvironment [9]? A first explanation proposed that thymic epithelial cells (TEC) were responsible for T-cellpositive selection, whereas other thymic bone-marrowderived stromal cells (macrophages and dendritic/interdigitating (IDC) cells) induced deletion of self-reactive Tcell clones [10]. However, this hypothesis is no longer supported by recent experiments which have established that TEC are able to delete self-reactive T cells (see after). The 'avidity/affinity hypothesis' has been proposed as another explanation of the thymic paradox $[11,12]$. This hypothesis is based on experiments showing that transgenic TCRs (specific for defined antigens) do not mature in organ cultures of fetal thymuses from MHC class I-defective animals. However, they do so if peptides related to the cognate antigen of TCR are added in the cultures. So T lymphocytes are positively selected if their TCR is barely engaged with self peptide presented by MHC ligands, and they are deleted if their TCR is strongly engaged. However, since the usual affinity of a TCR for its cognate antigen is already rather low $\left(10^{-8} M\right.$ at the maximum), one may question the importance of the biological effects mediated by a lower affinity. If the experiments mentioned above have convincingly shown that $\mathrm{T}$-cell positive selection is peptide-specific and depends on ligand concentration, one may also question the nature and the amount of peptide/MHC combinations that contribute in vivo to positive selection of a particular TCR in a normal thymus. Because of their high polymorphism, thymic molecules derived from MHC cannot establish the dis- 
crimination between self and nonself antigens. Given the hazardous nature of the recombination of TCR gene segments, the precise identity of thymic peptides supporting T-cell positive and negative selection has become an important current question [13].

\section{Thymic Neurohypophysial-Related Peptides}

At the beginning of this century, Ott and Scott [14] described the galactogogue activity of thymic extracts after injection into the goat. At that time, oxytocin (OT) had not been identified as the primary mediator of the galactokinesis and the oxytocic activity of thymic extracts was not further characterized. TEC and thymic nurse cells (TNC) from different species synthesize polypeptide precursors of the neurohypophysial family, with a dominance of the OT lineage [15-21]. The oxytocic action of human fetal thymic extracts was also described [22]. TNC in the subcapsular and outer cortex of thymic lobules constitute an intimate neuroendocrine-immune microenvironment since their epithelial component (but not the TNC-engulfed pre-T cells) produces neurohypophysialrelated peptides and expresses the phenotype of neuroendocrine cell types [23]. Transcripts of proOT and proVP were detected both in human [17] and murine [24] thymic extracts, and the intrathymic expression of neurohypophysial genes during ontogeny is under current investigation. However, the synthesis of OT in TEC/TNC is not coupled with the secretion of the nonapeptide or its neurophysin in the supernatant of human TEC/TNC primary cultures. As shown in the murine thymus, immunoreactive (ir)-OT is not located in secretory granules but is diffuse in the cytosol, in vesicles of the endoplasmic reticulum, and associated with keratin filaments [25]. Interestingly, similar ultrastructural features were also reported for OT and VP expressed by murine spleen eosinophillike cells [26].

As discussed above, the thymic function is closely associated with the presentation of the self molecular structure to developing $\mathrm{T}$ cells. This action was long thought to be mediated by thymic macrophages and IDC only, but there is now large evidence that TEC/TNC are actively involved in the induction of central self tolerance [97, 98]. Using the appropriate methodology, we provided evidence that the presentation of thymic OT implicates a hybrid $55-\mathrm{kD}$ protein probably bearing a neurophysin $(10 \mathrm{kD})$ and a MHC class I heavy chain domain (45 kD) [29]. Following this putative explanation, the MHC class I domain would be implicated in membrane targeting of this hybrid protein, whereas neurophysin could bind OT for presentation to pre-T cells. In relationship with our studies, other authors have shown the translocation of a neurophysin-like material in the cell membranes of cancer cells. They also provided several arguments supporting the behavior of neurohypophysial-related peptides as candidate tumoral antigens $[30,31]$. Thus, both in the hypothalamo-neurohypophysial axis and in the thymus, the neurophysin part of the OT precursor fulfills the same function: binding of the active nonapeptide OT and transport to the external limit of neurons or TEC/TNC. The tyrosine residue in position 2 of OT and VP plays an important role in their binding to neurophysin [32]. Interestingly, the residue tyrosine in the same position was found to play a crucial role in the binding of antigens to some MHC class I alleles for their presentation [33].

As another argument for an antigenic role of thymic OT, we have shown that the immunological recognition of OT by specific mAbs at the outer surface of human TEC plasma membrane induced a marked secretion of the cytokines interleukin(IL)-6 and leukemia inhibitory factor (LIF) in the supernatant of TEC cultures [34]. Given the nature of the epitopes recognized by anti-OT mAbs, we were able to conclude that thymic OT is fully processed at the level of the TEC plasma membrane. The absence of biological effects following the treatment of TEC cultures with anti-VP mAbs supports our hypothesis that thymic OT behaves as the self antigen of the neurohypophysial hormone family.

\section{Intrathymic Cryptocrine Signaling}

The model of cell-to-cell cryptocrine signaling has been proposed by Funder [35] to characterize the direct membrane-to-membrane exchange of chemical information between large epithelial nursing cells and immature elements which migrate and differentiate at their contact. Besides its role as a self antigen, there is also evidence that OT mediates a cryptocrine-type signaling between TEC/ TNC and pre-T cells. Neurohypophysial peptide receptors have been detected in the rat thymus and on rat thymocytes [36, 37], on a murine pre-T cell line $\left(\mathrm{RL}_{12}-\mathrm{NP}\right)$ [38] and on murine cytotoxic T cells [38, 39]. Estrogens were shown to increase the affinity of OT receptors in the rat thymus [40]. Interestingly, the expression of the rat V1b (or V3) receptor was recently identified in tissues outside the anterior pituitary, including the thymus [41]. Already in 1969, the mitogenic effect of neurohypophysial peptides on rat thymocytes was described [42], where- 
as OT was reported to stimulate glucose oxidation by rat thymocytes [43]. On the basis of antagonist effects, murine pre-T cells express a V1 (or V3) subtype of neurohypophysial receptor, while mature cytotoxic $\mathrm{T}$ cells harbor receptors of the OT type; this observation suggests that the neurohypophysial reception system expressed by $\mathrm{T}$ lymphocytes could 'mature' in parallel with their stage of differentiation. In both of T-cell types, neurohypophysial peptide receptors transduce OT and VP via the phosphoinositide pathway and neurohypophysial-related signals increase the incorporation of tritiated thymidine by freshly isolated murine thymocytes suggesting a mitogenic effet [38]. Western blots of $\mathrm{RL}_{12}$-NP-extracted proteins with anti-phosphotyrosine revealed a number of proteins the phosphorylation of which was stimulated either by OT or VP. Two of these proteins were precipitated with anti-focal adhesion (FAK) mAb 2A7 and were identified one as p125 $15^{\mathrm{FAK}}$ and the other as a co-precipitating $130-\mathrm{kD}$ protein (probably p130 Cas). Another protein phosphorylated by OT in $\mathrm{RL}_{12}-\mathrm{NP}$ cells was identified as paxillin, a $68-\mathrm{kD}$ protein located at focal adhesion sites and associated with $\mathrm{p} 125^{\mathrm{FAK}}$. Interestingly, OT was more potent than $\mathrm{VP}$ in inducing $\mathrm{p} 125^{\mathrm{FAK}}$ phosphorylation and this OT effect was inhibited by a V1 receptor antagonist, confirming that immature $\mathrm{T}$ cells bear a V1-type neurohypophysial receptor [44]. Stimulation of focal adhesions could play an important role in promoting T-cell interactions with the thymic cellular microenvironment which are fundamental for the T-cell differentiation programme. There is thus large experimental evidence that thymic OT mediates a functional cryptocrine signaling that could serve as an accessory pathway in the positive selection of $\mathrm{T}$ cells.

The existence of a functional signaling between thymic OT and neurohypophysial receptors expressed by immature and cytotoxic $\mathrm{T}$ cells raises the possibility of a pharmacological modulation of T-cell activity by OT receptor antagonists. Using the methodology of whole blood cell cultures, OT hexapeptide antagonists (developed by Merck Sharp \& Dohme Research Laboratories) were shown to inhibit the production of IL- $1 \beta$ and IL-6 elicited by human T-cell activation with anti-CD3 mAb [45]. Specific antagonists of OT receptors expressed by immune cells could offer a therapeutic benefit in circumstances during which an enhancement of the immune reactivity and a relapse of autoimmune diseases are observed (such as during the postpartum or during lactation).

\section{Application to Other Neuroendocrine Polypeptide Families}

A number of neuroendocrine-related polypeptides have been detected and characterized in TEC and thymic stromal cells from different species (table 1). The wellcharacterized neuropeptides neurotensin (NT) and somatostatin have been extracted from the chicken thymus, especially after hatching, and were characterized both immunochemically and chromatographically [46]. We have shown the expression of ir-NT at the cell surface of human TEC. Cultured human TEC contain $\sim 5 \mathrm{ng}$ ir-NT/ $10^{6}$ cells, of which $5 \%$ is associated with plasma cell membranes. HPLC analysis of ir-NT present in human TEC revealed a major peak of ir-NT corresponding to intact $\mathrm{NT}_{1-13}$. Ir-NT was not detected in the supernatant of human TEC primary cultures. Using an affinity column prepared with an anti-MHC class I Ab, NT-related peptides were retained on the column and were eluted together with MHC class I proteins [47].

Neurokinin A (NKA) is the peptide of the tachykinin family encoded in human and rat TEC by the preprotachykinin A (PPT-A) gene [48]. Thymic PPT-A expression was shown to be glucocorticoid-dependent since adrenalectomy of Sprague-Dawley rats markedly enhanced the levels of thymic PPT-A (and NPY) mRNAs [Ericsson and Geenen, unpubl. data]. Interestingly, NKA exerts IL-1like mitogenic effects on murine thymocytes [49], and this effect suggests the expression of specific tachykinin receptors by immature $\mathrm{T}$ cells which could be implicated in another accessory pathway for T-cell maturation and positive selection. The amino-acid sequence of NKA shares the same C-terminal epitope with other members of the tachykinin family, and the leucine residue in position 9 could be used in the binding to some MHC class I alleles, thus making NKA the self antigen of the tachykinin family. The other tachykinin encoded by $P P T-A$, substance $\mathrm{P}$ (SP), is not detected in TEC but within sensory nerve fibers of the thymus [50]. Thymic-specific receptors for SP are associated with the vasculature in the medulla, where they could control local blood flow and vascular permeability [51].

The expression within the rat thymus of natriuretic peptides (ANP, BNP and CNP) has been well documented. ANP seems to be the dominant thymic peptide and is expressed by thymic macrophages, while ir-CNP has been detected in thymocytes. The different types of natriuretic peptide receptors were also detected by RTPCR $[52,53]$. The treatment with ANP of murine fetal thymic organ cultures (FTOC) was shown to decrease the 
Table 1. The thymic repertoire of neuroendocrine self peptides

\begin{tabular}{|c|c|c|}
\hline Neuroendocrine families & Physiological aspects & Thymic repertoire \\
\hline \multicolumn{3}{|l|}{ Neurohypophysial peptides } \\
\hline Vasopressin (VP or ADH) & $\begin{array}{l}\text { Water metabolism } \\
\text { Vasocontriction }\end{array}$ & $\mathrm{OT} \gg \mathrm{VP}$ \\
\hline Oxytocin (OT) & $\begin{array}{l}\text { Reproduction } \\
\text { (CNS and periphery) }\end{array}$ & \\
\hline \multicolumn{3}{|l|}{ Insulin family } \\
\hline Insulin & Glucose metabolism & IGF-2 $>$ IGF-1 $\gg$ Insulin \\
\hline Insulin-like growth factor 1 (IGF-1) & Growth control & \\
\hline Insulin-like growth factor 2 (IGF-2) & Fetal development & \\
\hline \multicolumn{3}{|l|}{ Parathormones } \\
\hline Parathormone $(\mathrm{PTH})$ & Calcium metabolism & PTH-rP >> PTH [106] \\
\hline \multicolumn{3}{|l|}{ Parathormone-related peptide (PTH-rP) } \\
\hline \multicolumn{3}{|l|}{ Calcitonins } \\
\hline Calcitonin (CT) & Calcium metabolism & CGRP $>>C T[107]$ \\
\hline \multicolumn{3}{|l|}{ Calcitonin gene-related peptide (CGRP) } \\
\hline \multicolumn{3}{|l|}{ Tachykinins } \\
\hline Substance P (SP) & Pain - inflammation & NKA $\gg$ SP (NKB?) \\
\hline \multirow{2}{*}{\multicolumn{3}{|c|}{ Neurokinin A (NKA) }} \\
\hline & & \\
\hline \multicolumn{3}{|l|}{ Neurokinin B (NKB) } \\
\hline \multicolumn{3}{|l|}{ Natriuretic peptides } \\
\hline ANP & Sodium metabolism & ANP? \\
\hline \multicolumn{3}{|c|}{ 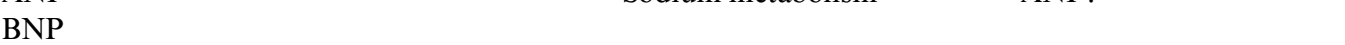 } \\
\hline \multicolumn{3}{|l|}{ CNP } \\
\hline \multicolumn{3}{|l|}{ Neuromedins } \\
\hline \multirow[t]{3}{*}{ Neurotensin $(\mathrm{NT})$} & Hypothermia & NT \\
\hline & Analgesia & \\
\hline & Pancreatic exosecretion & \\
\hline Neuromedin $\mathrm{N}$ & Vasodilatation & \\
\hline
\end{tabular}

total thymocyte yield in FTOC, to increase the CD4-8and to decrease the CD4+8+ thymocyte subpopulations [54].

It has to be mentioned that a series of anterior pituitary hormone immunoreactivities have been detected in different TEC subpopulations of the human thymus. These TEC populations were different from OT/VP/neurophysin-containing epithelial cells. However, it is not yet clear whether these hormones are locally synthesized or stored in TEC from peripheral blood [55], though they were identified in cultured rat thymic fragments [56].

Importantly, the expression of thymic hormones has been shown to be under the control of the neuroendocrine and steroid microenvironment [57], and this will be discussed in detail in another chapter.

\section{Thymic Expression of Insulin-Related Genes}

In the line of our working model that central T-cell tolerance of neuroendocrine functions is induced by the thymic repertoire of neuroendocrine self antigens, a series of investigations were undertaken to identify the dominant member of the insulin family expressed in the thymic microenvironment. By immunocytochemistry with a panel of specific Abs directed against distinct epitopes of the insulin family, ir-IGF-2 was clearly identified as the dominant member of the insulin family expressed by TEC/TNC [58]. A mAb against proinsulin [59] revealed a slight labeling but outside thymic lobules, in the interstitial tissue of the thymic capsule and in interlobular septae. Thymic labeling was also negative with mAbs against the C-terminal part of the insulin B chain. A few IGF-1-posi- 
tive cells were also stained in thymic lobules but they were not epithelial; their distribution and morphology were similar to those of macrophages. Of interest, murine macrophages were shown to express IGF-1 Ea and Eb transcripts [60]. Interferon- $\gamma$ inhibits macropage IGF-1 at the transcriptional level [61], whereas colony-stimulating factors induce IGF-1 mRNA [62]. Ir-IGF-2 was not detected in the supernatant of human TEC primary cultures and, with the use of confocal microscopy, a large part of irIGF-2 was found to be associated with the outer surface of TEC plasma membranes. This was not the case for either IGF-1 or insulin. In the human thymus, IGF-2, IGF-1 and (pro)insulin concentrations were respectively $96.7 \pm$ $10.6 \mathrm{ng} / \mathrm{g}, 42.9 \pm 5.0 \mathrm{ng} / \mathrm{g}$, and $<0.1 \mathrm{ng} / \mathrm{g}$ wet weight. $I G F 2$ transcripts have been isolated from whole human thymic extracts, as well as from primary cultures of human TEC. With RT-PCR and different specific primers, the expression of $I G F 2$ in the human thymus was found to be controlled by the same promoters as in other fetal and adult extrahepatic tissues $[63,64$, and Kecha et al., submitted]. The effects of $I g f 2$ overexpression under the control of the $\mathrm{MHC} \mathrm{H}-2 \mathrm{~K}^{\mathrm{b}}$ promoter have been investigated by the generation of transgenic mice. The highest levels of transgene expression were found in thymus and spleen. Only the thymus showed a significant increase of weight in these transgenic mice, in agreement with the high mRNA expression within this organ [65].

Going back to the initial observations made by Pansky et al. [66], there is evidence that the thymic insulin-like reticular factor isolated by them corresponds in fact to IGF-2. The IGF-2 structure closely related to (pro)insulin explains a cross-reactivity with the polyclonal Abs directed against insulin that were used in 1965. The hypoglycemic properties of IGF-2 have been well described [67] and might explain the biological activity of thymic extracts on glucose metabolism. Moreover, the syndrome of hypoglycemia and lymphoid leukemia associated with thymic hyperplasia of some AKR female mice could in fact result from the overexpression of $I g f 2$ in hyperplastic thymic epithelium, with a subsequent secretion of IGF-2 in the bloodstream, and a profoundly disturbed thymic T-cell lymphopoiesis.

The hypothesis of a central T-cell tolerance of the insulin family and, secondarily, of the peripheral insulinsecreting pancreatic islet $\beta$ cells was further supported by the observation that transcripts of proinsulin and of 67$\mathrm{kD}$ isoform of glutamic acid decarboxylase (GAD) genes can be detected in the murine thymus with 30 cycles of RT-PCR [68]. Thymic insulin gene (INS) expression was highest in perinatal mice and persisted until 12 weeks of age. Two recent papers confirmed these findings and reported that INS transcripts, as well as (pro)insulin protein can be detected at very low levels $(100-1,000 \mathrm{fmol} / \mathrm{g}$ wet weight) in the human fetal thymus $[69,70]$. The question of an illegitimate INS trancription was ruled out by the RIA detection of ir-(pro)insulin within thymic tissues. Preliminary in situ hybridization studies have shown the presence of INS transcripts within murine thymic IDC, but the protein could not be evidenced by immunocytochemistry [Homo-Delarche, pers. commun.].

A functional signaling mediated in the thymus by IGFs and IGF receptors is highly plausible because type 1 and type 2 IGF receptors have been detected on rat thymocytes and murine thymoma cells [71], on human phytohemagglutinin A (PHA)-activated T cells and on anti-CD3activated human T lymphocytes [72, 73]. Kooijman et al. [74] have described a differential expression of type 1 IGF receptors in relation to the stage of activation and differentiation of human $\mathrm{T}$ lymphocytes. Interestingly, in Igf2 transgenic mice, the increased thymic cellularity is associated with a stimulated generation of phenotypically normal T cells, in particular CD4 T cells [75]. In our hands, specific type 2 IGF receptors were detected on a murine immature $\mathrm{T}$-cell line $\left(\mathrm{RL}_{12}-\mathrm{NP}\right)$, as well as on Jurkat $\mathrm{T}$ cells [76]. By affinity cross-linking, the type 2 IGF receptor expressed by lymphocytes was found to have a molecular weight $( \pm 260 \mathrm{kD})$ similar to that found on other cells. We currently investigate the biological action of thymic IGFs on T-cell differentiation through the use of murine FTOC and with specific Abs against IGF receptors [Kecha et al., in preparation].

\section{Some Principles and Advantages of Thymic T-Cell Education to Neuroendocrine Self Antigens}

A model has been proposed according to which neuroendocrine-related thymic polypeptides engage two distinct types of interactions with pre- $\mathrm{T}$ cells depending on their involvement as self antigens of their family or as cryptocrine signals (table 2) [77]. The interaction of neuroendocrine self antigens with their corresponding TCR implies a binding of moderate affinity $\left(10^{-6}\right.$ to $\left.10^{-8} \mathrm{M}\right)$, but with a high power of discrimination. Neuroendocrine self antigens usually correspond to peptide sequences of neuroendocrine precursors which have been highly conserved during the evolution of their related family. On the other hand, cryptocrine signaling between thymic neuroendocrine-related peptides and their cognate receptors 
expressed by pre-T cells implies a high-affinity binding $\left(10^{-10}\right.$ to $\left.10^{-11} M\right)$, with a low discrimination. Moreover, a hierarchy of dominance appears in the organization of the polypeptide repertoire expressed in the thymus (table 1). This is very significant since self tolerance primarily concerns self determinants that are dominant on self molecules [78-80].

Some selective advantages appear from this model of thymic neuroendocrine-related precursors of cryptocrine signals and self antigens in T-cell positive and negative selection, respectively. A first advantage is the absence of a tight allelic restriction in thymic T-cell education to neuroendocrine families. Such an allelic restriction of central T-cell tolerance of neuroendocrine families was hardly conceivable and our data seem to indicate that it is not the case in reality. Concerning the presentation of thymic OT for example, our data suggest that, though MHC class I molecules are of course involved in the process, it is the invariant neurophysin domain of the hybrid membrane $55-\mathrm{kD}$ protein that binds OT for presentation to pre-T cells. Another selective advantage resides in the potential presentation to pre-T cells of the structure characteristic of the neurohypophysial family. With regard to the thymic presentation of NT, there is no physical constraint for a non covalent binding to $\mathrm{MHC}$ since this neuropeptide is a linear peptide (in contrast to cyclic OT and IGF-2). In addition, the C-terminal sequence of NT includes tyrosine, isoleucine and leucine residues which can all be used in the anchorage to most of the MHC class I alleles. Given these characteristics, it is logical to postulate that NT and NT-derived C-terminal fragments could behave as natural ligands for a majority (if not all) of MHC class I alleles. This hypothesis is also in agrement with the high degree of conservation of NT-related C-terminal region throughout evolution [81].

For IGFs, the role of binding and transport proteins is ensured by IGF-binding proteins (IGFBPs). IGFBPs have co-evolved with IGFs but they are not part of IGF precursors and are encoded by distinct genes. These proteins are thought to play a prominent role in regulating the bioavailability and distribution of IGFs [82, 83]. Interestingly, some IGFBPs are in close relationship with cell plasma membranes (through binding to integrins or the extracellular matrix), but their relationship with MHC as well as their potential implication in thymic IGF presentation to immature $\mathrm{T}$ cells deserve to be further investigated.
Table 2. The dual role of thymic neuroendocrine self peptides in T-cell differentiation

\begin{tabular}{|c|c|}
\hline Cryptocrine signalling & $\begin{array}{l}\text { Presentation of neuroendocrine } \\
\text { self antigens }\end{array}$ \\
\hline $\begin{array}{l}\text { Physiology } \\
\text { Accessory signal in T-cell } \\
\text { development and activation } \\
\text { (positive selection) }\end{array}$ & $\begin{array}{l}\text { Physiology } \\
\text { T-cell education to neuro- } \\
\text { endocrine families } \\
\text { (negative selection of self- } \\
\text { reactive T cells) }\end{array}$ \\
\hline $\begin{array}{l}\text { Pathophysiology } \\
\text { Oversecretion in the bloodstream } \\
\text { (paraneoplastic syndrome) }\end{array}$ & $\begin{array}{l}\text { Pathophysiology } \\
\text { Failure (or breakdown) of } \\
\text { imunological tolerance to } \\
\text { neuroendocrine families }\end{array}$ \\
\hline $\begin{array}{l}\text { Involvement in the biology of } \\
\text { T-cell lymphomas }\end{array}$ & $\begin{array}{l}\text { Autoimmune endocrine } \\
\text { diseases }\end{array}$ \\
\hline $\begin{array}{l}\text { Pharmacology } \\
\text { Immunomodulation by neuro- } \\
\text { peptide agonists or antagonists }\end{array}$ & $\begin{array}{l}\text { Pharmacology } \\
\text { 'Reprogramming' of the } \\
\text { immunological tolerance to } \\
\text { neuroendocrine families } \\
\text { 'Tolerogenic' vaccination for } \\
\text { prevention of autoimmune } \\
\text { endocrine diseases }\end{array}$ \\
\hline
\end{tabular}

\section{A Role Played by a Trouble in Thymic T-Cell Education in Autoimmunity?}

The development of an autoimmune disease affecting the neuroendocrine system may be viewed as a failure to develop or maintain tolerance to cellular or molecular components which are constitutively expressed by neuroendocrine cells (i.e. autoantigens such as insulin or GAD). In this view, a large body of research recently focused on the physiological mechanisms which underline the establishment of self tolerance and about the potential factors leading to its breakdown in autoimmunity. Though the relationship between lymphoepithelial structures and autoimmunity was suspected in 1962 by Burnet and Mackay [84], the question of a defective thymic T-cell negative selection or self education in the pathophysiology of autoimmune diseases has not been intensively investigated. Nevertheless, it was shown that neonatal thymectomy prevents the emergence of diabetes in an animal model of autoimmune type 1 diabetes, the Bio-Breeding (BB) rat [85]. In clinical practice also, thymectomy usually induces an improvement of patients suffering from autoimmune myasthenia gravis, especially when a thymoma (hyperplasia of thymic epithelium) is associated [86]. In both cases, the benefit of thymectomy might in fact result 
from the removal of the defective thymic censorship which is responsible for a continuous release and enrichment of the peripheral T-cell pool with intolerant and selfreactive lymphocytes. The development of diabetes is prevented by the transplantation of thymus from diabetesresistant (DR) to diabetes-prone (DP) BB rats [87]. The transplantation of the thymus from NOD mice to DR mouse strains was also shown to induce diabetes in the recipients [88]. While bone marrow transplantation is rather ineffective in preventing autoimmune diseases of $\mathrm{MRL} /+$ mice, thymus transplantation is a crucial factor for their prevention [89]. A defective process of thymic T-cell negative selection has been suggested on the basis that the thymus of DR BB rats contains thymocytes predisposed to autoreactivity [90]. Another argument is the observation that grafts of pure thymic epithelium from NOD mouse embryos to newborn C57BL/6 athymic mice induced CD4 and CD8 T-cell-mediated insulitis and sialitis [91]. At the histological level, a defect in thymic function could be linked to a disorganization of the microenvironment such as the giant perivascular spaces observed in the NOD mouse thymus [92], and the epithelial defects of BB rat thymus [93]. Recently, we examined the elution profiles of ir-IGFs in the thymus from Wistar-Furth (WF) normal rats, DR and DP BB rats. A peak of ir-IGF-2 > $10 \mathrm{ng} / \mathrm{ml}$ was observed in the G75 profile of WF thymus extracts; a peak around $1.5 \mathrm{ng} / \mathrm{ml}$ was eluted from DR BB rat thymic extracts, while IGF-2 concentrations were almost undetectable in DP BB rats [94]. Altogether, these observations support the hypothesis that a defective thymic censorship or T-cell self education might well take an active part in the pathophysiology of autoimmune type 1 diabetes.

\section{Neuroendocrine Self Antigens versus Autoantigens: Toward the Design of Tolerogenic Vaccines for the Prevention of Autoimmune Diseases?}

Three types of factors are usually thought to be implicated in the pathogeny of autoimmune diseases. (1) The effector immune components are CD4- and CD8-autoreactive $\mathrm{T}$ cells which are specifically oriented against a given target cell or molecule. These autoreactive $\mathrm{T}$ cells result from a spontaneous breakdown of T-cell tolerance, either at the central thymic and/or the peripheral level. (2) A series of extra- and intra-MHC genes have been demonstrated to be related to different autoimmune diseases. Some of these genes could intervene in the presen- tation of target autoantigens to autoreactive $\mathrm{T}$ lymphocytes, but others certainly not. (3) Finally, an environmental factor is involved and could be implicated in establishing a link between the target autoantigens and autoreactive $\mathrm{T}$ cells. A molecular mimicry between target autoantigens and microorganisms might play at this level and this hypothesis recently received some experimental support [95]. The intervention of microbial superantigens has also been proposed to activate peripheral autoreactive $\mathrm{T}$ cells [96]. A preventive strategy of autoimmune diseases can hardly been designed on the basis of the genetic components of autoimmune disease or the hazardous environmental factors. Manipulation of autoreactive $T$ cells seems to be a more promising way by which an efficient prevention of autoimmunity can be envisioned.

In the neurohypophysial family, evidence has been presented that OT seems to be the neurohypophysial self antigen. A strong immunological tolerance protects the OT lineage, more than the VP one, from an autoimmune aggression. Indeed, some cases of idiopathic diabetes insipidus have been shown to result from an autoimmune hypothalamitis oriented toward VP-producing neurons $[97,98]$. Given the implication of the OT lineage in the reproductive process, a stronger tolerance of this lineage is important for the preservation of the species. Thus, in the neurohypophysial family, while OT behaves as the self antigen, VP is suspected to be one target autoantigen of the autoimmune process. As discussed previously, this conclusion is also supported by the frequence and the titers of Abs induced by active immunization against neurohypophysial peptides [VP $>>0 T]$. An infiltration of the hypothalamo-neurohypophysial tract by inflammatory mononuclear cells has been observed repeatedly, both after active immunization against VP [99], and in spontaneous diabetes insipidus [98]. These observations suggest that hypothalamic magnocellular neurons express on their surface antigenic markers specific of their neurosecretory activity.

There is now substantial evidence that insulin is one important among other autoantigens tackled by various autoreactive components of the immune system both in animal and human type 1 diabetes [100, 101]. Moreover insulin is the specific marker of the pancreatic islet endocrine $\beta$ cells. Oral, intranasal and parenteral administration of insulin or insulin-derived dominant autoantigens have been shown to inhibit the occurrence of diabetes in animal models of type 1 diabetes [102, 103]. However, one cannot exclude the risk of priming or triggering autoimmunity by peripheral administration of an autoantigen [104]. Reprogramming the immunological tolerance that 
is thought to be broken in autoimmunity represents an attractive strategy for the prevention of devastating autoimmune diseases such as multiple sclerosis, rheumatoid arthritis or type 1 diabetes. Such reprogramming could be based upon the natural tolerogenic properties of the thymic epithelium. Instead of a classical vaccination (with immune activation and induction of memory immunocompetent cells), a form of tolerogenic vaccination is proposed that would lead to the deletion or the anergy of peripheral autoreactive T lymphocytes. The induction of T-cell tolerance following peptide vaccination has already been obtained with synthetic peptides representing cytotoxic CD8 epitopes of T cells oriented against tumor antigens or viruses [105]. An efficient and nontoxic prevention of autoimmune diseases, perhaps even their erad- ication, could depend upon the strategic choice that will be made between either the induction of tolerance to specific autoantigens following their parenteral administration, or the exploitation of the putative tolerogenic proporties of thymic self antigens.

\section{Acknowledgments}

V. Geenen is Senior Research Associate of the National Fund of Scientific Research (Belgium); H. Martens is supported by Télévie/ FRSM. Our studies have been performed with the financial help of the Juvenile Diabetes Foundation International, the Suzanne et Jean Pirart Fund of the Belgian Association of Diabetes, the National Fund of Scientific Research [Belgium], Télévie/FRSM, the Association contre le Cancer [Belgium], and the Foundation Léon Fredericq [Liège University Medical School].

\section{References}

1 Miller JFAP: Immunological function of the thymus: Lancet 1961;ii:748-749.

2 Geenen V, Kroemer G: Multiple ways to cellular immune tolerance. Immunol Today 1993; 14:573-575.

3 Dustin ML, Springer TA: Role of lymphocyte adhesion receptors in transient interactions and cell locomotion. Annu Rev Immunol 1991; 9:27-66.

4 Ritter MA, Rozing J, Schuurman HJ: The true function of the thymus? Immunol Today 1988 ; 9:189-193.

5 MacDonald HR, Glasebrook AL, Schneider R, Lees RL, Pircher H, Pedrazzini T, Kanagawa O, Nicolas JF, Howe RC, Zinkernagel RM, Hengartner $\mathrm{H}$ : $\mathrm{T}$ cell reactivity and tolerance to Mls $\alpha$-encoded antigens. Immunol Rev 1989; 107:89-108.

6 Von Boehmer H: The developmental biology of T lymphocytes. Annu Rev Immunol 1989;6: 309-326.

7 Sprent J, Webb S: Can self/nonself discrimination be explained entirely by clonal deletion? Res Immunol 1992;143:285-287.

8 Hogquist KA, Jameson SC, Bevan MJ: The ligand for positive selection of $\mathrm{T}$ lymphocytes in the thymus. Curr Opin Immunol 1994;6: 273-278.

9 Von Boehmer H: Thymic selection: A matter of life and death. Immunol Today 1992;13:454458.

10 Sprent J, Tough DT: Lymphocyte life-span and memory. Science 1994;265:1395-1400.

11 Ashton-Rickardt PG, Tonegawa S: A differential avidity model for T-cell selection. Immunol Today 1994;15:362-366.

12 Sebzda E, Wallace VA, Mayer J, Young RSM, Mak T, Ohashi PS: Positive and negative thymocyte selection induced by different concentrations of a single peptide. Science 1994;263: 1615-1618.
13 Allen PM: Peptides in positive and negative selection: A delicate balance. Cell 1994;76: 593-596.

14 Ott I, Scott JC: The galactogogue action of the thymus and corpus luteum. Proc Soc Exp Biol Med 1910;8:49.

15 Geenen V, Legros JJ, Franchimont P, Baudrihaye M, Defresne MP, Boniver J: The neuroendocrine thymus: Coexistence of oxytocin and neurophysin in the human thymus. Science 1986;232:508-511.

16 Markwick AJ, Lolait SJ, Funder JW: Immunoreactive arginine vasopressin in the rat thymus. Endocrinology 1986;119:1060-1064.

17 Geenen V, Legros JJ, Franchimont P, Defresne MP, Boniver J, Ivell R, Richter D: The thymus as a neuroendocrine organ. Synthesis of vasopressin and oxytocin in human thymic epithelium. Ann NY Acad Sci 1987;496:56-66.

18 Moll UM, Lane BL, Robert F, Geenen V, Legros JJ: The neuroendocrine thymus. Abundant occurrence of oxytocin-, vasopressin-, and neurophysin-like peptides in epithelial cells. Histochemistry 1988;89:385-390.

19 Argiolas A, Gessa GL, Melis MR, Stancampiano R, Vaccari A: Effects of neonatal and adult thyroid dysfunction on thymic oxytocin. Neuroendocrinology 1990;52:556-559.

20 Robert F, Geenen V, Schoenen J, Burgeon E, De Groote D, Defresne MP, Legros JJ, Franchimont P: Colocalization of immunoreactive oxytocin, vasopressin and interleukin-1 in human thymic epithelial neuroendocrine cells. Brain Behav Immun 1991;5:102-115.

21 Geenen V, Robert F, Martens H, Benhida A, Degiovanni G, Defresne MP, Boniver J, Legros JJ, Martial J, Franchimont P: At the cutting edge. Biosynthesis and paracrine/cryptocrine actions of 'self' neurohypophysial-related peptides in the thymus. Mol Cell Endocrinol 1991; 76: C27-C31.
22 Milan J, Barbijeri M, Kovacevic D, Arambasic M, Kartaljevic G, Natalic D, Pazin S: Identification of neuroendocrine oxytocic activity of the human fetal thymus. Thymus 1990;15: 181-185.

23 Geenen V, Defresne MP, Robert F, Legros JJ, Franchimont $\mathrm{P}$, Boniver J: The neurohormonal thymic microenvironment: Immunocytochemical evidence that thymic nurse cells are neuroendocrine cells. Neuroendocrinology 1988; 47:365-368

24 Geenen V, Vandersmissen E, Martens H, Goxe B, Kecha O, Legros JJ, Lefèbvre PJ, Benhida A, Rentier-Delrue F, Martial JA: Cellular and molecular aspects of thymic T-cell education to neurohypophysial principles; in Saito T, Kurokawa K, Yoshida S (eds): Neurohypophysis: Recent Progress of Vasopressin and Oxytocin Research. Amsterdam, Elsevier, 1995, pp 309319.

25 Wiemann M, Ehret G: Subcellular localization of immunoreactive oxytocin within thymic epithelial cells of the male mouse. Cell Tissue Res 1993; 273:79-87.

26 Kumamoto K, Matsuura T, Amagai T, Kawata $\mathrm{M}$ : Oxytocin-producing and vasopressin-producing eosinophils in the mouse spleen: Immunohistochemical, immuno-electron-microscopic and in situ hybridization studies. Cell Tissue Res 1995;281:1-10.

27 Webb SR, Spent J: Tolerogenicity of thymic epithelium. Eur J Immunol 1990;20:25252528.

28 Lorenz RG, Allen PM: Thymic cortical epithelial cells can present self-antigens in vivo. Nature 1989;337:560-562.

29 Geenen V, Vandersmissen E, Cormann-Goffin N, Martens H, Legros JJ, Degiovanni G, Benhida A, Martial J, Franchimont P: Membrane translocation and relationship with MHC class I of a human thymic neurophysin-like protein. Thymus 1993;22:55-66. 
30 Rosenbaum LC, Neuwelt EA, Van Tol HHM, Peng Loh Y, Verbalis J, Hellström I, Hellström KE, Nilaver G: Expression of neurophysinrelated precursor in cell membranes of a smallcell lung carcinoma. Proc Natl Acad Sci USA 1990;87:9928-9932.

31 North WG, Yu X: Forms of neurohypophysial peptides generated by tumors, and factors regulating their expression. Regul Pept 1993;45: 209-216.

32 Griffin GH, Alazard R, Cohen P: Complex formation between bovine neurophysin- 1 and oxytocin, vasopressin and tripeptide analogs of their $\mathrm{NH}_{2}$-terminal region. J Biol Chem 1973; 248:7975-7978.

33 Maryanski JL, Romero P, Van Pel A, Boon T, Salemme FR, Cerrottini JC, Corradin G: The identification of tyrosine as a common key residue in unrelated $\mathrm{H}-2 \mathrm{~K}^{\mathrm{d}}$ restricted antigenic peptides. Int Immunol 1991;3:1035-1042.

34 Martens H, Malgrance B, Robert F, Charlet C, De Groote D, Heymann D, Godard A, Soulillou JP, Moonen G, Geenen V: Cytokine production by human thymic epithelial cells: Control by the immune recognition of the neurohypophysial self-antigen. Regul Pept 1996;67:3945.

35 Funder JW: Paracrine, cryptocrine, acrocrine. Mol Cell Endocrinol 1990;70:C21-C24.

36 Elands J, Resink A, De Kloet ER: Oxytocin receptors in the rat thymic gland. Eur J Pharmacol 1988;151:345-351.

37 Elands J, Resink A, De Kloet ER: Neurohypophysial hormone receptors in the rat thymus, spleen and lymphocytes. Endocrinology 1990; 126:2703-2710.

38 Martens H, Robert F, Legros JJ, Geenen V, Franchimont P: Expression of functional neurohypophysial peptide receptors by immature and cytotoxic T-cell lines. Prog Neuroendocrinimmunol 1992;5:31-39.

39 Torres BA, Johnson HM: Arginine vasopressin (AVP) replacement of helper cell requirement in IFNg production. Evidence for a novel AVP receptor on mouse lymphocytes. J Immunol 1988;81:132-136.

40 Caldwell JD, Walker CA, Noonan LR, Jirikowski GF, Peterson G, Pedersen CA, Mason GA: Changes in thymic oxytocin receptors during early development and in steroid-treated adult rats. Prog NeuroendocrinImmunol 1991; 4:223-233

41 Lolait SJ, O’Carroll AM, Mahan LC, Felder CC, Button DC, Young WS III, Mezey E, Brownstein MJ: Extrapituitary expression of the rat V1b vasopressin receptor gene. Proc Natl Acad Sci USA 1995;92:6783-6787.

42 Whitfield JF, Perris AD, Youdale T: The calcium-mediated promotion of mitotic activity in rat thymocyte populations by growth hormone, neurohormones, parathyroid hormone and prolactin. J Cell Physiol 1969;73:203209.

43 Goren HJ, Okabe T, Lederis K, Hollenberg MD: Oxytocin stimulates glucose oxidation in rat thymocytes. Proc West Pharmacol Soc 1984;27:461.
44 Martens H, Kecha O, Charlet-Renard C, Defresne MP, Geenen V: Neurohypophysial peptides stimulate the phosphorylation of pre-T cells focal adhesion kinases. Neuroendocrinology 1998;67:282-289.

45 Geenen V, Martens H, Robert F, VrindtsGevaert Y, De Groote D, Franchimont P: Immunomodulatory properties of cyclic hexapeptide oxytocin antagonists. Thymus 1992;20: 217-226.

46 Sundler F, Carraway RE, Hakanson R, Alumets J, Dubois MP: Immunoreactive neurotensin and somatostatin in the chicken thymus. A chemical and histochemical study. Cell Tissue Res 1978;194:367-376.

47 Vanneste Y, Ntodou Thome A, Vandersmissen E, Charlet C, Franchimont D, Martens H, Lhiaubet AM, Schimpff RM, Rostène W, Geenen V: Identification of neurotensin-related peptides in human thymic epithelial cell membranes and relationship with major histocompatibilty complex class I molecules. J Neuroimmunol 1997;76:161-166.

48 Ericsson A, Geenen V, Robert F, Legros JJ, Vrindts-Gevaert Y, Franchimont P, Brene S, Persson H: Expression of preprotachykinin A and neuropeptide-Y messenger RNA in the thymus. Mol Endocrinol 1990;4:1211-1218.

49 Söder O, Hellström PM: The tachykinins neurokinin A and physalaemin stimulate murine thymocyte proliferation. Int Arch Allergy Appl Immunol 1989;90:91-96.

50 Geppetti P, Theodorsson-Norheim E, Ballerini G, Alessandri M, Maggi CA, Santicioli P, Amenta F, Fanciullacci M: Capsaicin-sensitive tachykinin-like immu-noreactivity in the thymus of rats and guinea pigs. J Neuroimmunol 1988;19:3-9.

51 Shigematsu K, Saavedra JM, Kurihara M: Specific substance $\mathrm{P}$ binding sites in rat thymus and spleen: In vitro autoradiographic study. Regul Pept 1986;16:147-156.

52 Vollmar AM, Schulz R: Atrial natriuretic peptide is synthesized in the human thymus. Endocrinology 1990;126:2227-2281.

53 Vollmar AM, Wolf R, Schulz R: Co-expression of the natriuretic peptides (ANP, BNP, CNP) and their receptors in normal and acutely involuted rat thymus. J Neuroimmunol 1995;57: 117-127.

54 Vollmar AM: Influence of atrial natriuretic peptide on thymocyte development in fetal thymic organ culture. J Neuroimmunol 1997; 78:90-96.

55 Batanero E, De Leeuw FE, Jansen GH, Van Wicken DF, Huber J, Schuurman HJ: The neural and neuroendocrine component of the human thymus. Brain Behav Immun 1992;6:249_ 264

56 Martin-Fontecha A, Broekhuizen R, De Heer C, Zapata A, Schuurman HJ: The neuroendocrine component of the rat thymus: Studies on cultured thymic fragments before and after transplantation in congenitally athymic and euthymic rats. Brain Behav Immun 1993; 7:1-15.

57 Savino W, Dardenne M: Immune-neuroendocrine interactions. Immunol Today 1995;16: 318-322.
58 Geenen V, Achour I, Robert F, Vandersmissen E, Sodoyez JC, Defresne MP, Boniver J, Lefèbvre PJ, Franchimont P: Evidence that insulin-like growth factor 2 is the dominant thymic peptide of the insulin superfamily. Thymus 1993;21:115-27.

59 Sodoyez JC, Koch M, Lemaire I, Sodoyez-Goffaux F, Rapaille A, François-Gérard C, Sondag D: Influence of the affinity of antibodies upon their detection by liquid phase radiobinding assay and solid phase enzyme-linked immunosorbent assay: Demonstration using monoclonal antibodies raised against rDNA human proinsulin. Diabetologia 1991;34:463-468.

60 Arkins S, Rebeiz N, Biragyn A, Reese DL, Kelley KW: Murine macrophages express abundant insulin-like growth factor-I $\mathrm{Ea}$ and $\mathrm{Eb}$ transcripts. Endocrinology 1993;133:23342343.

61 Arkins S, Rebeiz N, Brunke-Reese DL, Biragyn A, Kelley KW: Interferon-gamma inhibits macrophage insulin-like growth factor-I synthesis at the transcriptional level. Mol Endocrinol 1995;9:350-360.

62 Arkins S, Rebeiz N, Brunke-Reese DL, Minshall $\mathrm{C}$, Kelley $\mathrm{KW}$ : The colony-stimulating factors induce expression of insulin-like growth factor-I messenger ribonucleic acid during hematopoiesis. Endocrinology 1995;136:11531160.

63 Kecha O, Achour I, Hodzic D, Goxe B, Winkler R, Geenen V: IGF-II expression in the human thymus. Proc 10th Int Congr Endocrinol 1996, abstr P1-659.

64 Kecha O, Achour I, Martens H, Winkler R, Lefèbvre PJ, Geenen V: Characterization of the insulin-like growth factor (IGF) axis in the human thymus. Proc 79th Annu Meeting Endocr Soc, 1997, abstr P3-263.

65 van Buul-Offers SC, de Haan K, Reijnen-Gresnigt MG, Meinsma D, Jansen M, Oei SL, Bonte EJ, Sussenbach JS, Van den Brande JL: Overexpression of human insulin-like growth factor II in transgenic mice causes increased growth of the thymus. J Endocrinol 1995;144:491-502.

66 Pansky B, House EL, Cole LA: An insulin-like thymic factor. A preliminary report. Diabetes 1965;14:325-332.

67 Zapf J, Hauri C, Waldvogel M, Froesch ER: Acute metabolic effects and half-lives of intravenously administered insulin-like growth factors I and II in normal and hypophysectomized rats. J Clin Invest 1986;77:1768-1775.

68 Jolicœur C, Hanahan D, Smith KM: T-cell tolerance toward a transgenic $\beta$-cell antigen and transcription of endogenous pancreatic genes in the thymus. Proc Natl Acad Sci USA 1994; 91:6707-6711.

69 Vafiadis P, Bennett ST, Todd JA, Nadeau J, Grabs R, Goodyear CG, Wickramasinghe S, Colle E, Polychronakos C: Insulin expression in human thymus is modulated by INS VNTR alleles at the IDDM2 locus. Nat Genet 1997;15: 289-292. 
70 Pugliese AA, Zeller M, Fernandez A Jr, Zalcberg LJ, Bartlett RJ, Ricordi C, Pietropaolo M, Eisenbarth GS, Bennett SJ, Patel DD: The insulin gene is transcribed in the human thymus and transcription levels correlate with allelic variation at INS VNTR-IDDM2 susceptibility locus for type 1 diabetes. Nature Genet 1997; 15:293-297.

71 Verland S, Gammeltoft S: Functional receptors for insulin-like growth factors I and II in rat thymocytes and mouse thymoma cells. Mol Cell Endocrinol 1989;67:207-216.

72 Kozak RW, Hassell JF, Greenstein LA, Rechler MM, Waldmann TA, Nissley SP: Type 1 and 2 insulin-like growth factor receptors on human phytohemagglutinin-activated lymphocytes. Cell Immunol 1987;109:318-331.

73 Johnson EW, Jones LA, Kozak RW: Expression and function of insulin-like growth factor receptors on anti-CD3-activated human T lymphocytes. J Immunol 1992;148:63-71.

74 Kooijman R, Scholtens LE, Rijkers GT, Zegers BJM: Differential expression of type 1 insulinlike growth factor receptors in different stages of human T cells. Eur J Immunol 1995;25:931935.

75 Kooijman R, van Buul-Offers SC, Scholtens LE, Schuurman HJ, Van den Brande JL, Zegers BJM: T cell development in insulin-like growth factor-II transgenic mice. J Immunol 1995; 154 : 5736-5745.

76 Goxe B, Martens H, Vandersmissen E, Achour I, Kecha O, Geenen V: Interactions entre les cellules $\mathrm{T}$ et la famille insulinique: étude du récepteur de l'IGF-II. Ann Endocrinol 1995; 56:399.

77 Martens H, Goxe B, Geenen V: The thymic repertoire of neuroendocrine-related self-antigens: Physiological implications in T-cell life and death. Immunol Today 1996;17:312-317.

78 Gammon G, Sercarz E: How some T cells escape tolerance induction. Nature 1989;342: 183-185.

79 Adorini L, Appella E, Doria G, Nagy ZA: Mechanisms influencing the immunodominance of T cell determinants. J Exp Med 1988; 168:2091-2104.

80 Cabaniols JP, Cibotti R, Kourilsky P, Kosmatopoulos K, Kanellopoulos J: Dose-dependent $\mathrm{T}$ cell tolerance to an immunodominant self peptide. Eur J Immunol 1994;24:1743-1749.

81 Carraway RE, Ruane SE, Kim HR: Distribution and immunochemical character of neurotensin-like material in representative vertebrates and invertebrates: Apparent conservation of the $\mathrm{COOH}$-terminal region during evolution. Peptides 1982;3:115-123.
82 Clemmons DR, Busby WH, Arai T, Nam TJ, Clarke JB, Jones JI, Ankrapp DK: Role of insulin-like grow factor binding proteins in the control of IGF actions. Prog Growth Factor Res 1995;6:357-366.

83 Kelley KM, Oh Y, Gargosky SE, Gucev Z, Matsumoto T, Hwa V, Ng L, Simpson DM, Rosenfeld RG: Insulin-like growth factor-binding proteins and their regulatory dynamics. Int $\mathrm{J}$ Biochem Cell Biol 1996; 6:619-637.

84 Burnet FM, Mackay IR: Lymphoepithelial structures and autoimmune disease. Lancet 1962;ii:1030-1033.

85 Like AA, Kislaukis E, Williams RM, Rossini AA: Neonatal thymectomy prevents spontaneous diabetes mellitus in the $\mathrm{BB}: \mathrm{W}$ rat. Science 1982;216:644-646.

86 Newsom-Davis J: Myasthenia gravis. Med Int 1987;48:1988-1991.

87 Georgiou HM, Bellgrau D: Thymus transplantation and disease prevention in the diabetesprone Bio-Breeding rat. J Immunol 1989;142: 3400-3405.

88 Georgiou HM, Mandel TE: Induction of insulitis in athymic (nude) mice. The effect of NOD thymus and pancreas transplantation. Diabetes 1995;44:49-59.

89 Hosaka N, Nose M, Kyogoku M, Nagata N, Miyashima S, Good RA, Ikehara S: Thymus transplantation, a critical factor for correction of autoimmune disease in aging MRL/+ mice. Proc Natl Acad Sci USA 1996;93:8558-8562.

90 Whalen BJ, Rossini AA, Mordes JP, Greiner DL: DR-BB rat thymus contains thymocyte populations predisposed to autoreactivity. Diabetes 1995;44:963-967.

91 Thomas-Vaslin V, Damotte D, Coltey M, Le Douarin NM, Coutinho A, Salaün J: Abnormal $T$ cell selection on NOD thymic epithelium is sufficient to induce autoimmune manifestations in C57BL/6 athymic nude mice. Proc Natl Acad Sci USA 1997;94:4598-4603.

92 Savino W, Carnaud C, Luan JJ, Bach JF, Dardenne M: Characterization of the extracellular matrix-containing giant perivascular spaces in the NOD mouse thymus. Diabetes 1993;42: 134-140.

93 Doukas J, Mordes JP, Swymer C, Niedzwiecki D, Mason R, Rozing J, Rossini AA, Greiner DL: Thymic epithelial defects and predisposition to autoimmune diabetes in BB rats. Am J Pathol 1994;145:1517-1525.

94 Geenen V, Achour I, Kecha O, Greiner DL, Rossini AA, Lefèbvre PJ: Thymic insulin-like growth factors in man and in an animal model of autoimmune IDDM. Diabetologia 1996;39 (suppl 1):A15.

95 Atkinson MA, Maclaren NK: The pathogenesis of insulin-dependent diabetes mellitus. N Engl J Med 1994;331:1428-1436.
96 Conrad B, Weidmann E, Trucco G, Rudert WA, Behboo R, Ricordi C, Rodriquez-Rilo H, Finegold D, Trucco M: Evidence for superantigen involvement in insulin-dependent diabetes mellitus aetiology. Nature 1994;371: 351-355.

97 Scherbaum WA, Bottazzo GF: Autoantibodies to vasopressin cells in idiopathic diabetes insipidus: Evidence for an autoimmune variant. Lancet 1983;i:897-901.

98 Imura H, Nakao K, Shimatsu A, Ogawa Y, Sando T, Fujisawa I, Yamabe H: Lymphocytic infundibuloneurohypophysitis as a cause of central diabetes insipidus. N Engl J Med 1993;329:683-689.

99 Cau P, Rougon-Capuzzi G: Autoimmune alterations in the neurohypophysis of rabbits immunized against vasopressin. Brain Res 1979;177:265-271.

100 Simone EA, Yu L, Wegmann DR, Eisenbarth GS: T cell receptor gene polymorphisms associated with anti-insulin, autoimmune $\mathrm{T}$ cells in diabetes-prone NOD mice. $\mathrm{J}$ Autoimmun 1997;10:317-321.

101 Daniel D, Gill RG, Schloot N, Wegmann DR: Epitope specificity, cytokine production profile and diabetogenic activity of insulin-specific $\mathrm{T}$ cell clones isolated from NOD mice. Eur J Immunol 1995;25:1056-1062.

102 Zhang ZJ, Davidson L, Eisenbarth GS, Weiner HL: Suppression of diabetes in nonobese diabetic mice by oral administration of porcine insulin. Proc Natl Acad Sci USA 1991; 88:10252-10256.

103 Daniel D, Wegmann DR: Protection of nonobese diabetic mice from diabetes by intranasal or subcutaneous administration of insulin peptide B-(9-23). Proc Natl Acad Sci USA 1996;93:956-960.

104 Blanas E, Carbone FR, Allison J, Miller JFAP, Heath WR: Induction of auto-immune diabetes by oral administration of autoantigen. Science 1996;274:1707-1709.

105 Toes RM, Offringa R, Blom RJJ, Melief CJM, Kast WM: Peptide vaccination can lead to enhanced tumor growth through specific Tcell tolerance induction. Proc Natl Acad Sci USA 1996;93:7855-7860.

106 Kramer S, Reynolds FH Jr, Castillo M, Valenzuela DM, Thorikay M, Sorvillo JM: Immunological identification and distribution of parathyroid hormone-like protein polypeptide in normal and malignant tissues. Endocrinology 1991;128:1927-1937.

107 Bulloch K, McEwen BS, Diwa A, Baird S: Relationship between dehydro-epiandrosterone and calcitonin gene-related peptide in the mouse thymus. Am J Physiol 1995;268: E168-E173. 